\title{
APPLICATION OF TRIP GENERATION MODELS FOR URBAN TRANSPORT PLANNING IN A DATA SCARCE DEVELOPING COUNTRY CITY: THE CASE OF DAR ES SALAAM
}

\author{
Hannibal Bwire
}

Department of Transportation and Geotechnical Engineering, University of Dar es Salaam, P.O. BOX 35131 Dar es Salaam, Tanzania.

E-mail: bw_hann@yahoo.co.uk

\begin{abstract}
With the increase in travel demand and traffic management problems in many developing countries cities, travel demand forecasting models are being employed increasingly to make informed decisions about the operational improvements to the existing transportation system and the design and performance of future transportation systems. The main advantage of using travel demand forecasting models for such purposes is that they are capable of capturing the interactive effects of different components of the system under study. However, for some time now there have been concerns about the application of transport planning models in developing countries. The concerns have been mainly in relation to the variables, coefficients and models borrowed from developed countries. This paper first discusses the characteristics of transport problems in developing cities and provides a review of trip generation modelling approaches. Then, the discussion extends further to cover available data for urban transport planning and trip generation models that have found application in Dar es Salaam, Tanzania. The paper concludes by highlighting how available data sources and trip generation modelling approach can be improved to cope with the dynamic conditions in Dar es Salaam.
\end{abstract}

Key Words: Developing Countries, Urban Transport Planning, Trip Generation Models

\section{INTRODUCTION}

Substantial documentation and reviews exist about the existing conditions, problems and resources in the developing countries. Stopher (1980), Bayliss (1981), Willumsen (1981), Khan and Willumsen (1986), Dimitriou (1992), Yanaguaya (1993), Gaurav et al. (1998), Cervero and Mason (1998), GTZ (2010) and Aderamo (2012) just to mention a few, have discussed the existing conditions, problems and resources in the developing countries in the context of urban transport in developing countries. There are a number of ways in which the characteristics of the conditions and of the transport problems could be conceptualised. Drawn from the literature above, these conditions can be described as follows.

- The socioeconomic dimension includes factors such as rapid urbanisation, urban sprawling, the dual character of the economy (affluent versus poor population segments), limited financial resources, low and uneven income levels, and the lack of effective landuse control and regulations.

- The transport dimension includes factors such as fast rates of car ownership (higher energy consumption, congestion and environmental problems), poor transport infrastructure, deficient road signs, poor driver behaviour, bad road safety records, indiscriminate 
on-street parking, inadequate traffic enforcement, diversity of traffic composition, poor public transport services, increasing public transport demand, increasing trip distances, and proliferation of street vendors.

- The planning dimension includes factors such as the lack of effective and efficient planning framework and articulated planning goals; the lack of quality and reliable spatial data; the lack of committed professionals; the lack of appropriate institutional arrangements and willingness to plan city growth, manage urban transport systems and infrastructure development; inconsideration of future uncertainty in planning; and the preoccupation with transport projects rather than transport strategies for sustainable urban development.

Although some transport problems in developing countries bear some similarities with those prevalent in developed countries (e.g. congestion and pollution), the above factors underlie the basis of contrast between these countries. Some factors have a direct effect on the capability to solve urban transport problems and on the quality of urban life such as accessibility and environment. However, not all the above factors may necessarily be found in any particular developing country city. Likewise, there may be variations in intensities of each factor between cities.

With the increase in travel demand and traffic management problems in many developing countries cities, transport planning models are being employed increasingly to make informed decisions about the operational improvements to the existing transportation system and the design and performance of future transportation systems. However, transport planning models in developing countries have been adapted from developed countries since the 1960s. They found application in developing countries through consultants from developed countries (Thomson, 1983; Barbera, 1988; and Dimitriou, 1992). Further, the continued preoccupation of developing countries with transport projects rather than transport strategies (for sustainable urban development) as the incubator of transport projects has been questioned in contemporary transport planning cycles (Dimitriou, 1998).

The classic four-step transport modelling approach is still the standard practice for most strategic transport planning, although advanced approaches explore more realistic representations of travel behaviour in transport modelling. The first step in the classic four-step model is that of trip generation. This step serves many purposes, primarily the prediction of the number of trips attracted to and generated by land uses/traffic analysis zones in a study area (Chang et al., 2014). These predictions are useful in the planning and design of highway facilities and traffic management schemes. The trip generation models are available for land uses in many developed countries, but they may not be adequate and appropriate for use in a developing country city, such as Dar es Salaam. This is because of the differences in the cultural and socioeconomic background of the traveller and also in the type of land use that exist in the different settings. Overall, the four-step modelling approach is resource-intensive to develop and apply and has therefore limited its application in data scarce developing countries cities. Consequently, efforts to apply urban transport planning models in developing countries have been of varying degree from country to country as many countries lack quality data and capabilities for applying transport models (McDonald et al., 2002).

It is therefore necessary to develop and apply models that will appropriately 
describe the trip-making patterns as well as be operated and maintained for resource-constrained conditions in developing countries cities. Thus, the objectives of this paper are to identify and assess data sources available for urban transport planning as well as trip generation models that have found application in a data scarce developing country city of Dar es Salaam.

\section{LITERATURE REVIEW}

The commonly used methods for trip generation modelling are growth factors methods, regression methods and category analysis. Ortúzar and Willumsen (2001) showed that growth factor methods for trip generation can overestimate the total number of trips by $42 \%$ and they are therefore used in practice to predict the future number of external trips to the study area as these are not too many and errors cannot be too large and there are no simple ways to predict them.

In the 1950s and 1960s, most of the transport studies developed tripgeneration models, particularly person trip-production models using multiple linear regression method. Zonal-based trip production models were developed as a function of such zonal socioeconomic variables as land use, characteristics of households as well as individual characteristics such as employment, profession, car ownership, and median family income (Chang et al 2014). However, the aggregate models lack the context of travellers' behaviour. Household-based trip generation models are more common in current practice, even though they require an additional process of obtaining zonal-level totals (Papacostas and Prevedouros, 2001).

Regression models have generated an acceptable level of performance from the perspective of transport planning. Critical problems, however, have also been observed as summarised by Chang et al. (2014). The number of trips is treated as a continuous random variable though it is a discrete one. The dependent variable may take on negative values due to the assumption of a normal distribution for the disturbance of trip rates, which is obviously unrealistic. Furthermore, the method does not represent traveller behaviour theory because it simply matches a statistical relationship between the dependent variable and a set of independent variables.

In the 1970s and 1980s household-based trip generation models were developed using more disaggregate data at household levels in which such independent variables as income, vehicle ownership, and household size were used instead of zonal aggregations (Takyi, 1990). For more disaggregation in trip rate analysis, an alternative modelling of trip generation, the category analysis (also referred to as (cross-classification method) was developed (Takyi, 1990). This type of model uses categorized variables, such as household size, vehicle ownership, personal and median family income, and residents per households and so on, as integer values to describe individual household characteristics. The main advantages of the category analysis model are: it does not require a definite relationship (linear or monotonic) among the variables that affect the trip making and the model allows a more comprehensive analysis of trip making by showing the differences in relationships among different classes of any one variable by cross-classification (Takyi, 1990). The technique is independent upon the zonal system of the study area; no assumptions are required about the shape of the relationship between the trip rate and explanatory variables; it represents class specific behaviour; and it does not permit extrapolation beyond its 
calibration strata, although the lowest or highest class of a variable can be openended.

The category analysis method has also generated an acceptable level of performance from the perspective of transport planning. However, the method also has several drawbacks (Ortúzar and Willumsen, 2001). There is no effective way to choose independent variables and their strata for classification and therefore it requires an extensive 'trial and error' procedure which may be considered infeasible in practical studies. The method bears no statistical goodness-of-fit measures, so the calibration cannot be verified. The cell-by cell calculation reduces the reliability of cell values. In particular, the uncertainty increases when there are cells with small samples and/or large variances. This calculation mechanism also requires large sample sizes, which incurs much cost and time (Ortúzar and Willumsen, 2001).

An alternative approach to a simple category model for person trips (Stopher and McDonald, 1983) and for freight movements (Bastida and Holguin-Veras, 2009) is the Multiple Classification Analysis (MCA) method. This method overcomes the above-mentioned disadvantages of the category model. The method is basically a simple extension of analysis of variance (ANOVA) which itself is a powerful statistical method that can be used to identify the most appropriate variables of households and the classification schemes for the crossclassification models. It adopts a statistically justifiable approach based on analysis of variance (ANOVA). The cell value is estimated by the grand and the group means (Stopher and McDonald, 1983).

On the other hand, there has been research to overcome the disadvantages of regression models and category models.
Chang et al. (2014) provides a summary of the research done regarding the censored regression models, count data models, and ordered logit and probit models. Censored regression models such as Tobit analysis have been used to block the potential negative values on trip generation rates. Poisson and negative binomial models have been used to try to address the integer nature of the dependent variable. These count data models can also confine the figure of the trip rate greater than or equal to zero. Ordered logit and probit models have been understood as generalized frameworks in regression-based trip generation modelling since the discrete choice methods are, in principle, free from the three limitations of the likelihood of negative trip rates, the continuous dependent variable, and the lack of incorporation of traveller behaviour theory.

In a comparison study of the six representative models - regression, Tobit, Poisson, ordered logit, category, and multiple classification analyses, Chang et al. (2014) found that regression and category analyses have been widely applied in practice and the two methods have generated an acceptable level of performance from the perspective of transport planning. They noted that even if this result does not directly mean that the better performance model should become the standard framework for trip generation forecasting, the conventional models can be said to address a satisfactory trip-making behaviour. It should also be noted that the more sophisticated models have not shown better performance in terms of validation, though their implementation is more onerous. This does not mean that the models do not provide more advanced frameworks. Indeed, the models have more appealing theoretical bases compared to those of the conventional approaches (Chang et al., 2014). 


\section{METHODOLOGY}

This study involved a case study approach. To address the objectives of the study, identification of the organisations/ government departments involved in transport planning, data provision and the stakeholders was first carried out. This process also involved identification of available data types which have relevance to transport planning. The data types were then evaluated for their potential for application in transport planning in the case study city of Dar es Salaam. The available data sources were evaluated in terms of the usefulness of the data types and their limitations. This review and assessment were supplemented by contacting experts and practitioners involved in the transport data collection or use. Experts contacted for this outreach effort were given a draft of Table 1 to confirm the validity of assessment made regarding the usefulness and limitations of the available data sources. In total, approximately 30 practitioners provided feedback on the assessment made regarding the usefulness and limitations of the available data sources in the case study city. The outreach effort relied on "networking" and the ability of the author to find contacts willing to provide feedback. Because of the limited depth of the survey effort, it is possible that some data sources in the case study area may have been overlooked.

Assessment of the application of trip generation models in the case study city involved identification and evaluation of the types of models that have found application in the case study city. The evaluation of the models was accomplished by assessment of model input data types, data quality, model assessment based on input data variables and model reliability.

\section{EXISTING DATA SOURCES FOR URBAN TRANSPORT PLANNING}

A number of sources are potential for supporting urban transport planning efforts in the case study area. They, however, suffer from some limitations inherent in the generation of data. It is obvious that some limitations may be overcome, for instance by mounting extra efforts to acquire the data at the desirable level of detail. For example, census data can be provided at some finer details upon special requests and payment for the costs incurred to produce the data at the desirable details. Likewise, data such as employment can be verified in the field where is necessary. Table 1 shows current data sources from which transport data may be collected to support urban transport planning in Dar es Salaam. It also presents the usefulness and limitations of the available data.

A total of 11 data sources and 24 data types have been identified and assessed in terms of their usefulness and limitations. As presented in Table 1, actions for improving the data types should focus on overcoming the identified limitations. Apart from the assessment of the usefulness and limitation of available data types, it can be generally noted that there are a number of problems and challenges that need also to be overcome in order to ensure availability of quality and reliable transport planning data. These include:

- Lack of transport-related data from national census data

- Lack of reliable, up-to-date origin/destination data for goods and passengers;

- Lack of the number of vehicles which are actually operating on the road region-wise;

- Lack of activity data, both in terms of passenger kilometres and tonnage kilometres; 
- Lack of data on non-motorized transport infrastructure;

- Lack of an organization with a mandate and organizational capacity to integrate different data sets and disseminate transport data.

\section{APPLICATION OF TRIP GENERATION MODELS IN DAR ES SALAAM}

A number of transportation planning studies took place over the last 20 years as part of efforts to find solutions to the urban transport problems facing Dar es Salaam city. Notable ones, which involved the application of urban transport planning models, are as follows.

- Dar es Salaam Road Development Plan Study, 1993 (MOW and JICA, 1995).

- Dar es Salaam Transport Policy and System Development Master Plan Study, 2007 (DCC and JICA, 2008).

\section{The Dar es Salaam Road Development Plan Study, 1993}

This study was carried out in 1993 and its report was released in 1995. The study area covered an entire area of Dar es Salaam (DSM) region. The 4-step travel demand modelling approach was applied: estimation of future registered vehicles, estimation of future traffic generation/ attraction by traffic zones, estimation of future traffic distribution, estimation of traffic diversion from other modes of transport, and estimation of future traffic volume on road networks (MoW and JICA, 1995). Due to lack of reliable data on the number of registered vehicles in DSM and in Tanzania as a whole, time series data for vehicles in DSM were estimated by the study team using available data, which included an annual number of imported vehicles by the Customs Office, traffic accident data statistics by the Traffic Police, and income data by the Bureau of Statistics. In
Tanzania as a whole, the annual increase rate of $7 \%$ was obtained during 19781993 where the number of registered vehicles was estimated by vehicle type. Number of registered vehicles in DSM was estimated on the basis of this Tanzania total by applying income data of Tanzania, where $16.6 \%$ and $16.1 \%$ of shares of income of DSM in 1989 and 1993 were assumed respectively. As a result, $6.3 \%$ of annul increasing rates of registered vehicles during the period of total vehicle was obtained. The number of future registered vehicles was estimated via extrapolation of the past trend with an assumption that the share of economic activities of DSM would remain at the same levels (MoW and JICA, 1995).

Future total trip ends were estimated by applying same increasing rates of registered vehicles by type. Future generated/ attracted traffic by zone was estimated via decomposition of total trip ends in prorata with size of zone-wise population and employment. This decomposition was made by trip purpose for each vehicle type, adopting different index as decomposers (MoW and JICA, 1995).

\section{The Dar es Salaam Transport Policy and System Development Plan Study, 2007}

This study was carried out in 2007 and its report was released in 2008. The study area covered the entire area of Dar es Salaam (DSM) region. A conventional 4step transport modelling technique was employed. The study observed significant differences in travel behaviour between car owning and non-car owning households and therefore as a first step of the transport modelling process, a car ownership model was developed. The variable used to explain car owning household ratio at a traffic analysis zone was household income.

Trip generation models consisted of two models: trip production model at origin 
zone and trip attraction model at destination zone. The parameters for trip generation models were estimated by the regression modelling technique by using zonal attributes such as population and the number of employees. The model parameters were estimated by trip purposes of non-home based, home-based work, home-based school, home-based other, and non-home based other.

\section{EVALUATION OF MODELLING APPROACHES AND DISCUSSION OF RESULTS}

The 1993 study (MoW and JICA, 1995) used expansion factor method to predict future trips. The method simply relied upon the growth rate of the number of registered vehicles to predict the future total number of trips in the study area. At zonal level, the method relied upon population and employment indices to decompose the future total trip ends zonewise. The basic structure of the model formulation is shown in Equation 1.

$T_{i}=F_{i} t_{i}$

where $T_{i}$ and $t_{i}$ are respectively future and current trips in zone $i$ and $F_{i}$ is a growth factor.

On the other hand, the 2007 study (DCC and JICA, 2008) used regression analysis models to predict future trip ends zonewise. Separate models were developed to predict trip production and attraction. In trip production modelling separate models were developed to predict non-homebased home trips, home-based work trips, home-based school trips, home-based other trips, and non-home-based other trips for both car-owning and non-car owning households. Likewise, models to predict non-home-based home, homebased work, home-based school, homebased other and non-home-based other trip attractions were developed for both car owning household and non-car owning households. Table 2 presents the variables that were used to predict trip production and trip attraction.

Table 2: Explanatory Variables Used in Trip Production and Attraction Models

\begin{tabular}{|l|l|}
\hline \multicolumn{1}{|c|}{ Trip Production } & \multicolumn{1}{|c|}{ Trip Attraction } \\
\hline $\begin{array}{l}\text { Number of tertiary } \\
\text { employees by } \\
\text { workplace }\end{array}$ & $\begin{array}{l}\text { Number of tertiary } \\
\text { employees } \\
\text { workplace }\end{array}$ \\
\hline $\begin{array}{l}\text { Population of car } \\
\text { owned household }\end{array}$ & $\begin{array}{l}\text { Population of no-car } \\
\text { owned household }\end{array}$ \\
\hline $\begin{array}{l}\text { Total number of } \\
\text { students by resident } \\
\text { (car-owning } \\
\text { households) }\end{array}$ & $\begin{array}{l}\text { Total number of } \\
\text { students by resident } \\
\text { (no-car owning } \\
\text { households) }\end{array}$ \\
\hline $\begin{array}{l}\text { Number of secondary } \\
\text { school students }\end{array}$ & $\begin{array}{l}\text { Number of secondary } \\
\text { school students }\end{array}$ \\
\hline $\begin{array}{l}\text { Number of } \\
\text { university/college } \\
\text { students }\end{array}$ & $\begin{array}{l}\text { Number } \\
\text { university/college } \\
\text { students }\end{array}$ \\
\hline $\begin{array}{l}\text { Number of secondary } \\
\text { industries workers } \\
\text { (car-owning } \\
\text { households) }\end{array}$ & $\begin{array}{l}\text { Number of secondary } \\
\text { industries workers } \\
\text { (no-car owning } \\
\text { households) }\end{array}$ \\
\hline $\begin{array}{l}\text { Number of tertiary } \\
\text { industries workers } \\
\text { (car-owning } \\
\text { households) }\end{array}$ & $\begin{array}{l}\text { Number of tertiary } \\
\text { industries workers } \\
\text { (no-car owning } \\
\text { households) }\end{array}$ \\
\hline $\begin{array}{l}\text { Number of workers } \\
\text { (car-owning } \\
\text { households) }\end{array}$ & $\begin{array}{l}\text { Number of workers } \\
\text { (no-car owning } \\
\text { households) }\end{array}$ \\
\hline
\end{tabular}

Generally, the type of regression models employed used the structure shown in Equation 2.

$T_{i}=b_{0}+b_{1} z_{1 i}+b_{2} z_{2 i}+\ldots+b_{k} z_{k i} \ldots \ldots$

where $T_{i}=$ Number of trips of a given type (non-home-based home trips, homebased work trips, home-based school trips, home-based other trips, and nonhome-based other trips) made by zone $i$, $b_{k}=$ Coefficient estimated from household travel survey data and corresponding to characteristic $k$, and

$z_{k i}=$ Characteristic $k$ (as shown in Table 3) of zone $i$.. 
Table 1: Existing Data Sources in Dar es Salaam City

\begin{tabular}{|c|c|c|c|}
\hline Source & $\begin{array}{l}\text { Available } \\
\text { Data }\end{array}$ & Usefulness & Limitations \\
\hline \multirow[t]{6}{*}{$\begin{array}{l}\text { National } \\
\text { Bureau of } \\
\text { Statistics } \\
\text { (NBS) }\end{array}$} & $\begin{array}{l}\text { Population } \\
\text { census }\end{array}$ & $\begin{array}{l}\text { Number of inhabitants; } \\
\text { population groups } \\
\text { characteristics; age, } \\
\text { gender, household sizes }\end{array}$ & $\begin{array}{l}\text { - Missing other transport-related items } \\
\text { such as vehicle availability, place of } \\
\text { economic activity, etc. } \\
\text { - Aggregate information at } \\
\text { administrative level, such as at ward, } \\
\text { district and regional level. } \\
\text { - Limited accessibility of raw data }\end{array}$ \\
\hline & $\begin{array}{l}\text { Household } \\
\text { expenditure } \\
\text { survey }\end{array}$ & $\begin{array}{l}\text { Household } \\
\text { characteristics (e.g., } \\
\text { housing, education, } \\
\text { economic activities, and } \\
\text { head of household) }\end{array}$ & $\begin{array}{l}\text { - Nationwide. } \\
\text { - Information aggregated at the Dar es } \\
\text { Salaam regional level. }\end{array}$ \\
\hline & $\begin{array}{l}\text { Register of } \\
\text { establishments }\end{array}$ & 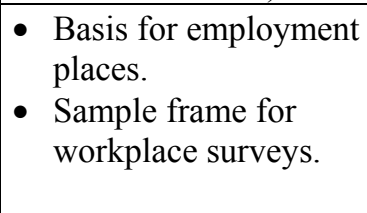 & $\begin{array}{l}\text { - Limited location and zonal } \\
\text { information. } \\
\text { - Uncertainty. } \\
\text { - Outdated. } \\
\text { - Limited accessibility }\end{array}$ \\
\hline & Business survey & $\begin{array}{l}\text { - Basis for employment } \\
\text { places. } \\
\text { - Sample frame for } \\
\text { workplace surveys. }\end{array}$ & $\begin{array}{l}\text { - Outdated } \\
\text { - Limited accessibility }\end{array}$ \\
\hline & GIS-based data & $\begin{array}{l}\text { Spatial data integration } \\
\text { and analysis that } \\
\text { enhance identification of } \\
\text { potential traffic zones } \\
\text { necessary for trip } \\
\text { forecasting }\end{array}$ & $\begin{array}{l}\text { - Available at course resolution } \\
\text { - Limited accessibility }\end{array}$ \\
\hline & $\begin{array}{l}\text { Economic indices } \\
\text { (e.g. regional per } \\
\text { capita, GDP) }\end{array}$ & $\begin{array}{l}\text { Per capita income } \\
\text { considered as a proxy } \\
\text { for income }\end{array}$ & $\begin{array}{l}\text { - } \text { Outdated. } \\
\text { - } \text { Limited accessibility }\end{array}$ \\
\hline $\begin{array}{l}\text { Water, } \\
\text { telephone } \\
\text { and } \\
\text { electricity } \\
\text { utility } \\
\text { companies }\end{array}$ & Consumer lists & $\begin{array}{l}\text { - Survey sample frame. } \\
\text { - Growth identification. }\end{array}$ & $\begin{array}{l}\text { Non-coverage due to lack of service } \\
\text { or because it is an unaffordable } \\
\text { service to other population segments. } \\
\text { - Limited physical \& postal addresses. }\end{array}$ \\
\hline $\begin{array}{l}\text { Vehicle } \\
\text { registration } \\
\text { department }\end{array}$ & $\begin{array}{l}\text { Vehicle } \\
\text { registration }\end{array}$ & $\begin{array}{l}\text { Vehicle growth, } \\
\text { distribution \& trend. } \\
\text { - Sample frame. }\end{array}$ & $\begin{array}{l}\text { - Available nationwide with limited } \\
\text { accessibility } \\
\text { - Lack of the number of vehicles which } \\
\text { are actually operating on the road } \\
\text { region-wise }\end{array}$ \\
\hline \multirow[t]{4}{*}{$\begin{array}{l}\text { City/ } \\
\text { Municipal } \\
\text { Councils }\end{array}$} & $\begin{array}{l}\text { Property tax } \\
\text { payers lists }\end{array}$ & $\begin{array}{l}\text { - Sampling frame. } \\
\text { - Growth identification. }\end{array}$ & $\begin{array}{l}\text { - Available with limited accessibility } \\
\text { - Occupants may be different from } \\
\text { owners. } \\
\text { - Multiple households. }\end{array}$ \\
\hline & $\begin{array}{l}\text { Primary \& } \\
\text { secondary school } \\
\text { places }\end{array}$ & $\begin{array}{l}\text { Education places or } \\
\text { enrolment }\end{array}$ & $\begin{array}{l}\text { - Available but incomplete as there is } \\
\text { limited information on private schools } \\
\text { - Limited accessibility }\end{array}$ \\
\hline & Road network & $\begin{array}{l}\text { Road network } \\
\text { information }\end{array}$ & $\begin{array}{l}\text { Available with limited accessibility } \\
\text { - Data available on spread sheet with } \\
\text { limited network attributes }\end{array}$ \\
\hline & $\begin{array}{l}\text { Land use } \\
\text { development plan }\end{array}$ & Land use information & $\begin{array}{l}\text { - Outdated and inaccurate } \\
\text { - Limited accessibility }\end{array}$ \\
\hline
\end{tabular}


Application of trip generation models for urban transport planning in a data scarce developing country city

\begin{tabular}{|c|c|c|c|}
\hline Source & $\begin{array}{l}\text { Available } \\
\text { Data }\end{array}$ & Usefulness & Limitations \\
\hline \multirow[t]{3}{*}{$\begin{array}{l}\text { Wards/ Sub- } \\
\text { wards }\end{array}$} & Resident registry & $\begin{array}{l}\text { - Survey sample frame. } \\
\text { - Growth identification. }\end{array}$ & $\begin{array}{l}\text { - Available but fragmented } \\
\text { - Incomplete and inaccurate } \\
\text { - Limited accessibility }\end{array}$ \\
\hline & $\begin{array}{l}\text { Ten-cells } \\
\text { (Matawi) resident } \\
\text { lists }\end{array}$ & $\begin{array}{l}\text { - Survey sample frame. } \\
\text { - Growth identification. }\end{array}$ & $\begin{array}{l}\text { - Available but fragmented } \\
\text { - Incomplete and inaccurate } \\
\text { - Limited accessibility }\end{array}$ \\
\hline & Electoral rolls & $\begin{array}{l}\text { - Survey sample frame. } \\
\text { - Growth identification. }\end{array}$ & $\begin{array}{l}\text { - Available but fragmented } \\
\text { - Incomplete and inaccurate } \\
\text { - Limited accessibility }\end{array}$ \\
\hline $\begin{array}{l}\text { TANROADS/ } \\
\text { Prime } \\
\text { Minister's } \\
\text { Office } \\
\text { Regional } \\
\text { Administratio } \\
\text { n and Local } \\
\text { Government } \\
\text { (PMORALG) }\end{array}$ & Road network & $\begin{array}{l}\text { Road network } \\
\text { information }\end{array}$ & $\begin{array}{l}\text { - Available with limited accessibility } \\
\text { - Incomplete (missing network } \\
\text { attributes such as capacities, speed } \\
\text { limits etc.) }\end{array}$ \\
\hline SUMATRA & $\begin{array}{l}\text { - } \text { Road transport } \\
\text { data including } \\
\text { public } \\
\text { transport data } \\
\text { - Marine } \\
\text { transport data }\end{array}$ & $\begin{array}{l}\text { - Vehicle licensing } \\
\text { - Route allocation and } \\
\text { monitoring } \\
\text { - Service quality and } \\
\text { safety standards } \\
\text { - Regulations } \\
\end{array}$ & Available with limited accessibility \\
\hline $\begin{array}{l}\text { Ministry of } \\
\text { education and } \\
\text { culture }\end{array}$ & $\begin{array}{l}\text { Higher } \\
\text { institutions places } \\
\text { School places }\end{array}$ & \multirow[t]{2}{*}{$\begin{array}{l}\text { - Education places } \\
\text { - Student enrolments }\end{array}$} & \multirow[t]{2}{*}{$\begin{array}{l}\text { - Available but incomplete } \\
\text { - Limited accessibility }\end{array}$} \\
\hline $\begin{array}{l}\text { Ministry of } \\
\text { Science and } \\
\text { Technology }\end{array}$ & Education places & & \\
\hline \multirow[t]{3}{*}{$\begin{array}{l}\text { Ministry of } \\
\text { lands, housing } \\
\text { and settlement }\end{array}$} & Base maps & $\begin{array}{l}\text { - Network background } \\
\text { information. } \\
\text { - Land uses }\end{array}$ & $\begin{array}{l}\text { - Available with difficulty accessibility } \\
\text { - Available at course spatial scale } \\
\text { (1:50,000 and 1:25,000) } \\
\text { - Outdated as were produced in } 1980 \text { 's }\end{array}$ \\
\hline & Aerial photos & $\begin{array}{l}\text { - Land use pattern. } \\
\text { - Network background } \\
\text { information. } \\
\text { - Household survey } \\
\text { sample frame. } \\
\text { - Dwelling units counts }\end{array}$ & $\begin{array}{l}\text { - Available with limited accessibility } \\
\text { - Outdated and available as raw aerial } \\
\text { photographs } \\
\text { - Some houses are unoccupied. } \\
\text { - Presence of multiple households. } \\
\text { - Time consuming to aggregate photos } \\
\text { to cover reasonable size of the study } \\
\text { area. }\end{array}$ \\
\hline & $\begin{array}{l}\text { Land use } \\
\text { development/rede } \\
\text { velopment plans } \\
\end{array}$ & Land use patterns & $\begin{array}{l}\text { - Available with limited accessibility } \\
\text { - Outdated and inaccurate }\end{array}$ \\
\hline $\begin{array}{l}\text { Planning } \\
\text { studies reports }\end{array}$ & $\begin{array}{l}\text { Prior information } \\
\text { from previous } \\
\text { transport studies }\end{array}$ & $\begin{array}{l}\text { Background information } \\
\text { ranging from trip } \\
\text { patterns, network } \\
\text { information, } \\
\text { performance data, land } \\
\text { uses, and forecasts. }\end{array}$ & $\begin{array}{l}\text { - Not centrally located. } \\
\text { - Quality of data collection varies from } \\
\text { study to study. } \\
\text { - Database or data files not readily } \\
\text { available. }\end{array}$ \\
\hline
\end{tabular}




\section{APPROACH TO EVALUATION}

Bwire (2007, 2008) presented a unified systematic procedure for selecting a suitable transport model for urban transport planning for developing cities. Basing on this procedure, the most relevant steps for evaluation of the trip generation models involve assessment of input data, model reliability assessment, and assessment of efforts for data provision.

\section{Model Input Data}

As shown in Table 3, almost all the data variables that were used to develop the models are limited at zonal level only.

\section{Data Quality Assessment}

In view of the criteria for assessment of data quality listed by Bwire $(2007,2008)$, the criterion of level of aggregation of data is the most applicable here with regard to the data types (shown in Tables 2 and 3) used to develop the models. Table 4 provides the assessment of the input data at three levels of aggregation; zonal, household and person levels.

\section{Model Data Needs Assessment}

This step involved the model assessment in terms of type of input data variables that are difficult to forecast and those which are unavailable or difficult to provide at the desirable level of aggregation. Table 4 presents a summary of the assessment in conjunction with the assessment of the input variables at various levels of data aggregation. It can be noted from the table that both models face almost similar data problems in terms of the absence of data at the household and person levels. Table 4 also shows that both models (expansion factor model and regression model) can easily be implemented at zonal and person levels. However, there is some flexibility of implementing a regression model at the zonal level as compared to an expansion factor model in view of the difficulties involved in providing and forecasting the envisaged input data.

\section{Model Reliability Assessment}

The expansion factor method is very crude as it overestimates trip ends and errors at this stage of trip generation modelling are carried through the entire four-step modelling process and may invalidate subsequent stages. Due to fast changing rate and complexity of urban areas, the expansion factor modelling approach is outdated and its use is confined to short term forecasting in small urban areas or rural areas or to predict external trips to an area (Ortúzar and Willumsen, 2001). On the other hand, a more pressing issue of the regression analysis method is the problem of accuracy in projections of exogenous variables such as population of carowning households and number of workers.

The two models show a typically static level of analysis, since they don't possess variables which can enable them to capture the urban changes related to land use as changes in land use are considerably higher and faster as is the case in the case study area. Apart from the disadvantages of the regression model, presented in the literature review section, regression models still provide acceptable results.

\section{Model Efforts Assessment}

This step involved the assessment of efforts required to implement, operate and maintain the models. Estimation of trip generation models requires information which usually can be reached through an extensive collection of data related to individual trips which require what is called an O-D study. This collection of data consumes the most part of the time for the planning study and demand the use of expensive human and financial resources, making the process sometimes 
invalid for most of the small and medium sized zones. Thus, the large quantity of data and time needed to execute the modelling impedes the updating of these data in a quick and continuous way due to the high operational cost. Further, the trip generation/attraction variables are extremely dynamic in many developing countries.

\section{CONCLUSION AND RECOMMENDATIONS}

This study has identified and evaluated a total of 11 data sources and 24 data types in terms of their usefulness and limitations. It is therefore recommended that actions for improving the data types should focus on overcoming the identified limitations.

Apart from the assessment of the usefulness and limitation of available data types, the study has also identified a number of problems and challenges that need also to be overcome in order to ensure availability of quality and reliable transport planning data. In this regard, it is recommended that there is a need to have an organization with a mandate and organizational capacity to integrate different data sets, share and disseminate transport data to stakeholders.
As for the application of trip generation models in the case study city, the study has found that the development and application of regression analysis models at zonal level done by the 2007 study of the Dar es Salaam Transport Policy and System Development Master Plan (DCC and JICA, 2008) was the most feasible trip generation modelling approach in view of the available data. Deficiency in the existing secondary data has been highlighted in relation to the application of regression and expansion factor models. In view of the deficiencies in the available data types and the problems associated with expansion factor method, regression model has proved to be the most appropriate model for trip generation modelling at zonal level in a data scarce developing country city. It should also be noted that the literature review results indicate that these models can appropriately be implemented at person level of analysis as well.

In search of an effective and efficient trip generation modelling approach, this study recommends the need for the development of a model that is capable of capturing dynamic changes in land use as well.

Table 3: Assessment of Data Used

\begin{tabular}{|c|c|c|c|c|c|}
\hline $\begin{array}{l}\text { Model } \\
\text { Type }\end{array}$ & Type of Data Used & $\begin{array}{l}\text { Regional/ } \\
\text { district } \\
\text { level }\end{array}$ & $\begin{array}{l}\text { Ward/ } \\
\text { Sub- } \\
\text { ward } \\
\text { Level }\end{array}$ & $\begin{array}{l}\text { Household } \\
\text { Level }\end{array}$ & $\begin{array}{l}\text { Person } \\
\text { Level }\end{array}$ \\
\hline \multirow{3}{*}{$\begin{array}{l}\text { Expansion } \\
\text { Factor } \\
\text { Model }\end{array}$} & Number of registered vehicles & $\mathrm{X}$ & & & \\
\hline & Population & $X$ & $\mathrm{X}$ & & \\
\hline & Employment & $\mathrm{X}$ & $\mathrm{X}$ & & \\
\hline \multirow{8}{*}{$\begin{array}{l}\text { Regression } \\
\text { Analysis } \\
\text { Models }\end{array}$} & Number of tertiary employees & $\mathrm{X}$ & $\mathrm{X}$ & & \\
\hline & Population of car owned household & $X$ & $\mathrm{X}$ & & \\
\hline & Total number of student by resident & $\mathrm{X}$ & $\mathrm{X}$ & & \\
\hline & Number of secondary school students & $\mathrm{X}$ & $\mathrm{X}$ & & \\
\hline & Number of university/college students & $\mathrm{X}$ & $\mathrm{X}$ & & \\
\hline & $\begin{array}{l}\begin{array}{l}\text { Number of secondary industries } \\
\text { workers }\end{array} \\
\end{array}$ & $\mathrm{X}$ & $\mathrm{X}$ & & \\
\hline & Number of tertiary industries workers & $X$ & $\mathrm{X}$ & & \\
\hline & Number of workers & $\mathrm{X}$ & $\mathrm{X}$ & & \\
\hline
\end{tabular}

Note: Blank cells mean data is unavailable and X means data is available 
Table 4: An Assessment of Input Data vs Trip Generation Models

\begin{tabular}{|c|c|c|c|c|c|c|c|c|c|c|}
\hline \multirow[b]{2}{*}{$\begin{array}{l}\text { Model } \\
\text { Type }\end{array}$} & \multirow[b]{2}{*}{ Data Input } & \multicolumn{3}{|c|}{ Zone } & \multicolumn{3}{|c|}{ Household } & \multicolumn{3}{|c|}{ Person } \\
\hline & & Unavailable & $\begin{array}{c}\text { Difficult } \\
\text { to } \\
\text { provide }\end{array}$ & $\begin{array}{c}\begin{array}{c}\text { Difficult } \\
\text { to } \\
\text { forecast }\end{array} \\
\end{array}$ & Unavailable & $\begin{array}{l}\text { Difficult to } \\
\text { provide }\end{array}$ & $\begin{array}{c}\begin{array}{c}\text { Difficult } \\
\text { to } \\
\text { forecast }\end{array} \\
\end{array}$ & Unavailable & $\begin{array}{c}\text { Difficult } \\
\text { to } \\
\text { provide }\end{array}$ & $\begin{array}{c}\begin{array}{c}\text { Difficult } \\
\text { to } \\
\text { forecast }\end{array} \\
\end{array}$ \\
\hline \multirow{3}{*}{ 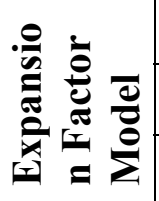 } & Number of registered vehicles & $\mathrm{X}$ & $\mathrm{X}$ & $\mathrm{X}$ & $\mathrm{X}$ & & & $\mathrm{X}$ & & \\
\hline & Population & & & & $\mathrm{X}$ & & & $X$ & & \\
\hline & Employment & & & & $\mathrm{X}$ & $\mathrm{X}$ & $\mathrm{X}$ & $\mathrm{X}$ & $\mathrm{X}$ & $\mathrm{X}$ \\
\hline \multirow{8}{*}{ 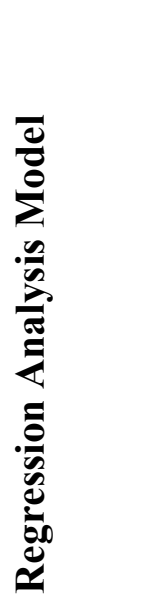 } & Number of tertiary employees & & & & $\mathrm{X}$ & $X$ & $X$ & $\mathrm{X}$ & $\mathrm{X}$ & $\mathrm{X}$ \\
\hline & $\begin{array}{l}\text { Population of car owned } \\
\text { household }\end{array}$ & $\mathrm{X}$ & $\mathrm{X}$ & $\mathrm{X}$ & $\mathrm{X}$ & & & $\mathrm{X}$ & & \\
\hline & Number of student by resident & $\mathrm{X}$ & & & $\mathrm{X}$ & & & & & \\
\hline & $\begin{array}{l}\text { Number of secondary school } \\
\text { students }\end{array}$ & $\mathrm{X}$ & & & $\mathrm{X}$ & & & & & \\
\hline & $\begin{array}{l}\text { Number of university/college } \\
\text { students }\end{array}$ & $\mathrm{X}$ & & & $\mathrm{X}$ & & & & & \\
\hline & $\begin{array}{l}\text { Number of secondary industries } \\
\text { workers }\end{array}$ & & & & $\mathrm{X}$ & $\mathrm{X}$ & $\mathrm{X}$ & $\mathrm{X}$ & $\mathrm{X}$ & $\mathrm{X}$ \\
\hline & $\begin{array}{l}\text { Number of tertiary industrial } \\
\text { workers }\end{array}$ & & & & $\mathrm{X}$ & $\mathrm{X}$ & $X$ & $\mathrm{X}$ & $\mathrm{X}$ & $\mathrm{X}$ \\
\hline & Number of workers & & & & $X$ & $X$ & $X$ & $X$ & $X$ & $X$ \\
\hline
\end{tabular}

Note: Blank cells indicate input data that was not used and X shows input data used 


\section{REFERENCES}

Aderamo A.J. (2012). Urban transportation problems and challenges in Nigeria: A planner's view, Prime Research on Education (PRE), ISSN: 2251-1253, 2(3): 198-203. Available on line at www.primejournal.org/PRE.

Barbera R. (1988). Use of Models by French Consultants for Urban Transport Planning in Developing Countries, Transportation Research Record, 1167: 41-45.

Bastida C. and Holguin-Veras J. (2009). Freight generation models, Transp. Res. Rec. J., Transp. Res. Board., 2097: 51-61.

Bayliss D. (1981). One Billion New City Dwellers - How Will They Travel?, Transportation, 10: 311-343.

Bwire H. (2007). Application Requirements and Selection Procedure for Urban Transport Planning Models for Developing Countries, PhD thesis, University of Dar es Salaam.

Bwire H. (2008). A Unified Framework for Selecting A Travel Demand Forecasting Model for Developing Countries, Transportation Planning and Technology, 31(3): 347-368.

Cervero R. and Mason J. (1998). Proceedings of the Conference on Transportation in Developing Countries, Clark Kerr Campus, University of California, Berkeley, Accessed from http://www.uctc.net/papers/387.pdf on 02.06.2003.

Chang J.S., Jung D., Kim J., Kang T. (2014). Comparative analysis of trip generation models: results using homebased work trips in the Seoul metropolitan area, Transportation Letters: The International Journal of Transportation Research, 6(2).

DCC (Dar es Salaam City Council) and JICA (Japanese International Corporation Agency) (2008). Dar es Salaam Transport Policy and System Development Master Plan, Final
Report, Dar es Salaam City Council, Dar es Salaam, Tanzania.

Dimitriou H.T. (1992). Urban Transport Planning: A Developmental Approach, Routledge, London, 184-217.

Dimitriou H.T. (1998). Visions for Action in Transportation Planning in the Developing World, in Cervero, R. and Mason, J. (eds.): Proceedings of the Conference on Transportation in Developing Countries, Clark Kerr Campus, University of California, Berkeley, Accessed from http://www.uctc.net/papers/387.pdf on 02.06.2003.

Gaurav R., Ernst \& Young L.L.P. and Khisty C.J. (1998). Strategies for Solving Urban Transportation Problems in Developing Countries, Road Management \& Engineering Journal, Accessed from http://www.usroads.com/journals/rmej/ 9811/rm98110.htm on 16.11.2001.

GTZ (2010). Challenges of urban transport in developing countries- a summary, Accessed from www.sutp.org - www.sutp.cn on 16.6.2015.

Khan M.A. and Willumsen L.G. (1986). Modelling Car Ownership and Use in Developing Countries, Journal of Traffic Engineering and Control, November, 554-560.

McDonald N.C., Porter C.D. and Gorham R. (2002). Availability of Travel Forecasting Methods and Data for Air Quality Planning in Developing Countries, Submitted for the $82^{\text {nd }}$ Annual Meeting of the TRB, Accessed online on 30.05.2015. Available at http://www.camsys.com/TRB 2003/p apers/ncm TRB03.pdf.

Ministry of Works (MoW), Tanzania and Japanese International Corporation Agency, JICA (1995). The Study on Dar es Salaam Road Development Plan, Unpublished Final Report, Dar es Salaam, Tanzania, March.

Ortúzar J. de D. and Willumsen L.G. (2001). Modelling Transport, 3rd 
edition, John Willey \& Sons Ltd., Chichester, West Sussex.

Papacostas C.S. and Prevedouros P.D.

(2001). Transportation Engineering and Planning, 3rd Edition, PrenticeHall India, 646-650.

Stopher P.R. (1980). Transferring Urban Transport Planning Methods to Developing Countries. The Highway Engineer, 8: 8-14.

Thomson J.M. (1983). Towards Better Urban Transport Planning in
Developing Countries, World Bank Staff Working Papers, Number 600.

Willumsen L.G. (1981). Appropriate Transport Planning Techniques for Developing Countries, In S: Yerreli (ed.): Transport Research for Social and Economic Progress, 341-352.

Yanaguaya W. (1993). The Use of U.K. Transport Models in Developing Countries, Traffic Engineering and Control, 10: 476-479. 